\title{
Pengembangan Media Puzzle Shalat Edukatif dalam Meningkatkan Kemampuan Ibadah Shalat Anak Usia 5-6 Tahun
}

\author{
Novi Eka Saputri ${ }^{1 \bowtie}$, Ria Novianti $^{2}$, Febrialismanto $^{3}$ \\ $(1,2,3)$ Pendidikan Guru Pendidikan Anak Usia Dini, Universitas Riau
}

$\triangle$ Corresponding author

(novi.eka5010@student.unri.ac.id)

\begin{abstract}
Abstrak
Penelitian ini bertujuan mengembangkan media puzzle shalat edukatif untuk meningkatkan kemampuan ibadah shalat anak usia 5-6 tahun dan mengetahui kelayakan dari media puzzle shalat edukatif yang dikembangkan. Penelitian ini merupakan penelitian R\&D (Research and Developmet) yang menggunakan prosedur pengembangan menurut teori Brog dan Gall. Teknik pengumpulan data dalam penelitian ini adalah teknik angket yang akan di isi oleh validator ahli media, ahli materi, dan ahli pendidik. Jenis data yang dihasilkan dan dianalisis dalam penelitian ini adalah deskriptif kuantitatif. Berdasarkan penilaian yang sudah dilakukan oleh para ahli materi, ahli media, dan ahli pendidik diperoleh rata-rata nilai produk secara keseluruhan yaitu 3,49 dengan kategori kelayakan yaitu "Layak". Sehingga dapat disimpulkan bahwa media puzzle shalat edukatif yang di kembangkan dalam penelitian ini dengan serangkaian langkah dan tahapan validasi ahi materi dan ahli media dinyatakan "Layak" untuk meningkatkan kemampuan ibadah shalat anak usia 5-6 tahun.
\end{abstract}

Kata Kunci: Puzzle Shalat Edukatif; Media Pembelajaran; Kemampuan Ibadah Shalat Anak Usia Dini

\begin{abstract}
This study aims to develop educational prayer puzzle media to improve the ability of children aged 5-6 to pray and to discover the feasibility of the developed educational prayer puzzle media. This study is an R\&D study (Research and Developmet) using development procedures according to Brog and Gall's theory. The data collection technique in this study is a questionnaire technique that will be completed by media expert validators, materials experts and expert educators. The type of data generated and analyzed in this study is descriptive quantitative. Based on the assessment conducted by materials experts, media experts and expert educators, the overall average product value is 3.49 with the qualifying category being "Eligible". Thus, it can be concluded that the educational prayer puzzle media developed in this study with a series of steps and stages of validation of the material and media experts are declared "feasible" to improve the ability of children aged 5-6 to pray.
\end{abstract}

Keyword: Educational prayer puzzle; learning media; prayer skills for young children

\section{PENDAHULUAN}

Anak usia dini merupakan individu yang berusia 0-8 tahun dan berada pada masa-masa keemasan atau yang sering dikenal dengan istilah golden age. Pada masa inilah anak usia dini mengalami pertumbuhan dan perkembangan yang begitu pesat. Sehingga pada masa ini, anak usia dini sangat perlu diberi stimulus dan pendidikan yang tepat, guna menunjang pertumbuhan dan perkembangan anak secara maksimal. Masa golden age sendiri merupakan masa yang tepat dalam membangun perkembangan mereka sehingga mereka dapat tumbuh dan berkembang menjadi dewasa yang mandiri dan berakhlak mulia.

Deborah Stipek (dalam Suyadi dan Maulidya, 2015) menyatakan bahwa untuk anak usia enam sampai tujuh tahun akan menaruh harapan yang tinggi untuk anak dapat berhasil belajar segala hal. Seperti yang kita ketahui bahwa anak usia dini merupakan individu yang aktif, dinamis, antusias, dan memiliki rasa ingin tahu yang tinggi terhadap apa yang mereka lihat, mereka sentuh, dan mereka dengar. Mereka akan banyak belajar melalui setiap pengalaman yang diberikan. Maka dari itu pemberian layanan pendidikan untuk anak usia dini akan sangat diperlukan.

Menurut Hazira (2010) pendidikan anak usia dini pada hakikatnya merupakan pendidikan ataupun suatu lembaga yang diselenggarakan dengan tujuan untuk memfasilitasi pertumbuhan dan perkembangan anak secara menyeluruh dalam upaya mengoptimalkan segala potensi perkembangan yang dimiliki oleh anak. Pendidikan anak usia dini merupakan sebuah upaya pembinaan yang ditujukan untuk anak usia dini dalam 
meningkatkan kemampuan jasmani dan rohani agar anak mampu menghadapi jenjang pendidikan berikutnya. Menurut Kamtini dan Mesra (2018) dalam pendidikan anak usia dini akan sangat memperhatikan setiap aspek perkembangan anak yaitu aspek motorik, aspek kognitif, aspek sosial emosional, aspek bahasa, dan tentunya aspek nilai agama dan moral.

Penanaman tentang keagamaan sejak dini tentunya akan sangat diperlukan, terutama dalam hal tata cara ibadah. Ibadah sendiri merupakan cara manusia untuk dapat mendekatkan diri kepada Tuhan Yang Maya Esa. Seperti yang kita tahu bahawa setiap agama memilki caranya masing-masing untuk melakukan ibadah, seperti contohnya adalah agama kristen yang melakukan ibadah dengan cara berdoa di gereja, lalu agama hindu yang melakukan puja di pura, kemudian agama budha yang melakukan puja di vihara, dan juga agama islam yang melakukan ibadah dengan cara melaksanakan shalat.

Ihsan dan Uswatun (2018) mengatakan bahwa pendidikan agama jauh lebih berat dari pada pengajaran pengetahuan umum karena pendidikan agama bukan hanya sekedar menanamkan iman dan keyakinan beragama saja, tetapi pada usia dini tersebut pendidikan agama sudah menyangkut amal perbuatan, hukum, serta kaidah yang menanamkan pengertian dan pemahaman. Maka dari itu, penanaman tentang keagamaan sejak dini tentunya akan sangat diperlukan. Diberikannya pendidikan agama yang tepat dan benar dalam pendidika islam di sekolah terutama pada anak usia dini akan dapat menjadi unsur paham dalam perkembangan agama dan moral serta kepribadian anak. Pemberian pendidikan tentang cara beribadah juga merupakan langkah dalam pendidikan agama islam pada anak usia dini, yang terutama adalah mengenalkan tentang shalat kepada anak usia dini. Seperti yang kita ketahui bahwa shalat merupakan tiang agama dari agama islam. Shalat sendiri merupakan sarana bagi seorang hamba untuk berkomunikasi pada Allah SWT. Shalat dilakukan dalam keadaan tubuh bersih dan suci. Maka dari itu sebelum melaksanakan shalat harus berwudu terlebih dahulu untuk mensucikan diri dari hadas kecil.

Mengenalkan shalat sejak dini kepada anak usia dini berarti melatih mereka untuk dekat kepada Allah SWT. Maka dari itu pengenalkan shalat kepada anak usia dini akan sangat diperlukan tentunya. Memperkenalkan shalat merupakan upaya dalam meningkatkan kemampuan nilai agama dan moral anak khususnya dalam kemampuan beribadah. Seperti yang tertera didalam Permendikbud No. 137 Tahun 2014 untuk kemampuan nilai moral dan agama anak usia 5-6 tahun, anak sudah mampu mengerjakan ibadah. Kemudian pada Keputusan Menteri Agama Republik Indonesia No. 792 Tahun 2018 untuk anak usia 5-6 tahun, anak sudah mampu melakukan gerakan shalat dengan urutan yang benar. Dengan artian bahwasanya anak usia 5-6 tahun seharusnya sudah bisa melakukan ibadah shalat dengan urutan gerak yang benar. Seperti yang kita tau bahwa anak usia dini merupakan individu yang belum bisa berpikir secara abstrak. Mereka masih belajar melalui hal- hal yang konkrit. Mereka masih lebih banyak meniru dan menyerap melalui pancainderanya. Maka disini pemanfaatan media dalam pembelajaran anak usia dini akan menjadi suatu solusi dalam melaksanakan pembelajaran yang menyenangkan.

Berdasarkan pengamatan yang telah peneliti lakukan di beberapa TK, terdapat beberapa masalah yang peneliti temui diantaranya adalah: 1) Masih banyak orang tua yang belum mengenalkan sholat sejak dini kepada anak-anak mereka, 2) beberapa anak di sekolah belum mengenal gerakan shalat secara berurutan dan benar, 3) saat pembelajaran tentang shalat masih banyak anak yang tidak memperhatikan, 4) guru hanya melakukan metode berceramah dan juga praktik shalat biasa tanpa menggunakan media dalam pembelajaran sholat.

Guslinda dan Rita Kurnia (2018) mengatakan secara umum media merupakan segala sesuatu yang dapat menjadi penyalur informasi dari sumber informasi kepada penerima informasi. Media pembelajaran sendiri merupakan suatu bentuk peralatan, metode, atau teknik yang digunakan dalam penyaluran pesan, membantu mempertegas bahan pelajaran, sehingga dapat membangkitkan minat dan motivasi murid atau anak didik dalam mengikuti proses belajar mengajar. Penggunaan media didalam pembelajaran ini akan menjadi hal yang menyenangkan untuk anak usia dini. Melalui media ini anak dapat belajar dengan cara yang berbeda dan tentunya akan sangat membuat anak lebih tertarik dalam belajar.

Salah satu media yang akan peneliti kembangkan dalam upaya mengenalkan ibadah shalat adalah media puzzle sholat edukatif. Di dalam media ini setiap gambar gerakan shalat akan dituangkan kedalam bentuk puzzle yang dapat disusun oleh anak dengan urutan gerakan shalat yang benar. Media puzzle sholat edukatif ini digunakan sebagai pengenalan gerakan sholat secara berurutan dengan cara yang lebih menyenangkan. Permainan melalui media puzzle shalat edukatif akan dibarengi dengan mengikuti gerakan yang sudah tersusun sebagai penguat anak dalam memahami gerakan shalat secara benar dan berurutan.

\section{METODE PENELITIAN}

Penelitian ini merupakan penelitian pengembangan (Research and Developmet) yang bertujuan untuk mengembangkan media puzzel shalat edukatif dalam meningkatkan kemampuan ibadah shalat anak usia 5-6 tahun. Menurut Sugiyono (2010) metode penelitian pengembangan adalah suatu metode penelitian yang bertujuan untuk menghasilkan suatu produk tertentu dan produk tersebut akan diuji keefektifannya. Penelitian ini menggunakan prosedur pengembangan menurut teori Brog dan Gall. Namun dalam hal ini 
peneliti membatasi langkah penelitian hanya sampai dengan tahapan revisi produk. Adapun langkah-langkah penelitaian yang dilakukan dalam penelitian ini adalah 1) potensi masalah, 2) pengumpulan data, 3) desain produk, 4) validasi produk, 5) revisi desain, dan 6) revisi produk.

Potensi masalah merupakan segala sesuatu yang apabila didayagunakan akan dapat menjadi nilai tambah, sedangkan masalah merupakan penyimpangan antara apa yang diharapkan dengan apa yang terjadi. Disini dapat disimpulkan bahwa masalah dapat menjadi sebuah potensi apabila kita dapat mendayagunakannya. Potensi dan masalah pada penelitian ini diperoleh dengan mengumpulkan informasi melalui observasi dan wawancara yang dilakukan pada guru di sekolah. Masalah yang terjadi dalam pembelajaran yaitu tidak tersedianya media yang sesuai dalam mengenalkan gerakan shalat dan hanya menggunakan metode berceramah. Hal ini menyebabkan beberapa anak kurang memperhatikan dan tidak fokus saat pembelajaran shalat. Oleh karena itu peneliti tertarik untuk mengembangkan media berupa puzzle yang dimodifikasi agar menjadi menarik dan membuat kegiatan pembelajaran shalat anak menjadi lebih menyenangkan.

Setelah ditemukannya potensi masalah, tahap selanjutnya adalah mengumpulkan berbagai informasi yang dapat digunakan sebagai sumber reverensi untuk perencanaan produk agar sesuai dengan kebutuhan anak usia 5-6 tahun. Dengan adanya media puzzle shalat edukatif ini, diharapkan dapat memfasilitasi anak dalam pengenalan gerakan shalat.

Dalam penelitian Research and Development produk yang dihasilkan bisa bermacam-macam. Dalam bidang pendidikan, produk yang dihasilkan diharapkan dapat meningkatkan produktivitas pendidikan seperti lulusan yang jumlahnya banyak, berkualitas, dan relevan dengan kebutuhan. Penelitian ini akan menghasilkan sebuah produk berupa puzzle gerakan shalat yang dimodifikasi menjadi lebih menarik. Puzzle shalat edukatif ini terbuat dari kayu. Pada media ini akan terdapat beberapa kepingan puzzle yang setiap kepingannya terdapat gambar gerakan shalat, mulai dari gerakan takbirratul ikhram sampai dengan gerakan salam. Pada puzzle ini akan di sediakan sebalas buah lampu berwarna biru dan satu buah lampu berwarna merah. Lampu biru akan menyala apabila anak memasang kepingan puzzle dengan urutan gerakan yang benar, kemudian lampu merah akan menyala apabila anak memasang kepingan puzzle dengan urutan gerakan yang salah. Pada puzzle ini juga akan terdapat suara doa dari setiap gerakan shalat apabila kepingan puzzle dipasang.

Validasi desain adalah suatu proses kegiatan yang dilakukan untuk menilai apakah rancangan produk lebih efektif dari bahan ajar yang sudah lama atau tidak. Dalam hal ini validasi desain menghadirkan beberapa pakar atau tenaga ahli media, ahli meteri, dan ahli pendidik yang sudah berpengalaman dalam menilai produk baru yang dirancang. Penilaian ini dilakukan untuk mengetahui kelemahan dan kekurangan dari produk yang dirancang. Kelemahan dan kekurangan tersebut nantinya akan direvisi agar dapat menghasilkan produk yang layak dan sesuai dengan kebutuhan.

Setelah desain produk di validasi melalui penilaian dari para ahli media, ahli meteri, dan ahli pendidik pada pembelajaran shalat, peneliti melakukan perbaikan pada desain produk yang telah dibuat berdasarkan dari hasil penilaian dan masukan-masukan para ahli media, ahli materi, dan ahli pendidik.

Revisi produk perlu dilakukan apabila ditemukannya kelemahan dan kekurangan dari produk yang dikembangkan yang kemudian produk akan direvisi berdasarkan hasil penilaian sebagai penyempurnaan produk agar produk dapat di produksi secara masal.

Penelitian ini sendiri bertujuan untuk mengembangkan suatu media yaitu media puzzle shalat edukatif. Maka dari itu subjek dari penelitian ini adalah media puzzle shalat edukatif yang akan diteliti kelayakannya untuk meningkatkan kemampuan ibadah shalat anak usia 5-6 tahun. Untuk memperoleh data penelitian ini menggukakan instrument penelitian yaitu berupa angket kelayakan media dan juga angket kelayakan materi yang akan diisi oleh ahli media dan juga ahli materi dengan kriteria penilaian memberikan skor 4 apabila sangat setuju, skor 3 apaliba setuju, skor 2 apabila tidak setuju, dan skor 1 apabila sangat tidak setuju. Hasil perolehan dari proses validasi selanjutnya akan diolah dengan menggunakan teknik analisi data dengan rumus sebagai berikut:

Keterangan:

$$
X=\left(\sum x i\right) / n
$$

$X:$ rata-rata penilaian dari para validator

xi: rata-rata skor hasil penilaian validator ke-i

n: banyaknya validator

Dengan

\section{xi $=($ jumlah skor)/(skor maksimal)}

Hasil dari skor rata-rata yang telah dicari kemudian akan dikonversikan pada pernyataan penilaian untuk menentukan kualitas dan tingkat kemanfaatan produk yang dihasilkan. Produk yang dikembangkan 
yaitu media puzzle shalat edukatif dapat dikatakan "layak" apabila memperoleh rentang skor $2,5 \leq x<3,25$ atau 3,25 $\leq x \leq 4,00$ dari seluruh penilaian ahli media dan ahli materi. Apabila rentang skor yang diperoleh $1 \leq$ $x<1,75$ atau $1,75 \leq x<2,5$ maka produk masih dikategorikan "tidak layak" dan harus dilakukan revisi produk.

\section{HASIL DAN PEMBAHASAN}

Penilaian kelayakan media yang peneliti kembangkan dilakukan melalui proses validasi materi produk dan juga validasi media yang dilakukan oleh ahli materi, ahli media, dan ahli pendidik. Proses validasi meteri yang dilakukan oleh ahli materi I dan ahli materi II dilakukan dalam satu tahapan untuk menghasilkan produk yang layak. Pada tahap validasi materi yang dilakukan oleh ahli materi I, materi produk memperoleh rata-rata nilai yaitu 2,57 dengan kategori yaitu "Baik". Kemudian pada tahap validasi materi yang dilakukan oleh ahli materi II, materi produk memperolah rata-rata nilai yaitu 3,43 dengan kategori yaitu "Sangat Baik". Kemudian hasil dari validasi ahli materi I dan juga ahli materi II di gabungkan dan memperoleh rata-rata nilai yaitu 3,00 dengan kategori "Baik" dan kriteria kelayakan yaitu "Layak". Pada tahap ini kedua ahli materi menyatakan bahwa materi yang ada dalam media puzzle shalat edukatif ini sudah baik dan tidak ada bagian yang harus diperbaiki, sehingga media ini sudah layak untuk digunakan tanpa adanya revisi.

Proses validasi media pada penelitian ini juga dilakukan dengan satu tahap untuk menghasilkan desain ataupun bentuk media yang layak. Dalam proses validasi media ini juga dilakukan oleh dua validator yaitu ahli media I dan ahli media II. Pada tahap validasi ahli media I diperoleh rata-rata nilai 2,56 dengan kategori yaitu "Baik". Kemudian pada tahap validasi ahli media II diperoleh rata-rata nilai 3,56 dengan kategori yaitu "Sangat Baik". Setelah itu hasil kedunya kemudian digabungkan untuk mengetahui perolehan rata-rata nilai untuk validasi ahli media I dan ahli media II yaitu 3,06 dengan kategori "Baik" dan kreteria kelayakan yaitu "Layak". Dalam tahapan ini kedua ahli media mengatakan bahwa untuk desain, bahan, bentuk maupun cara penggunaan media yang dikembangkan sudah bagus dan tidak ada bagian yang harus diperbaiki. Namun disini terdapat sedikit masukan dari validator mengenai video demonstrasi penggunaan media untuk lebih memperlihatkan bagaimana media ini benar-benar berfungsi sesuai dengan desain yang telah dirancang.

Selanjutnya para ahli pendidik juga melakukan proses validasi terhadap media yang peneliti kembangkan. Pada tahap validasi oleh ahli pendidik I diperoleh rata-rata nilai yaitu 3,13 dengan kategori yaitu "Baik". Kemudian tahap validasi oleh ahli pendidik II diperoleh rata-rata nilai yaitu 4,00 dengan kategori yaitu "Sangat Baik". Dan untuk tahap validasi oleh ahli pendidik III diperoleh nilai rata-rata yaitu 3,44 dengan kategori yaitu "Sangat Biak". Kemudian untuk tahap validasi oleh ahli pendidik IV diperoleh nilai rata-rata yaitu 3,81 dengan kategori yaitu "Sangat Baik". Kemudian selanjutnya untuk tahap validasi oleh ahli pendidik $V$ diperoleh nilai rata-rata yaitu 4,00 dengan kategori yaitu "Sangat Baik". Hasil dari seluruh penilaian oleh ahli pendidik kemudian dihitung secara keseluruhan dan diperoleh nilai rata-rata yaitu 3,68 dengan kategori "Sangat Baik" dan kriteria kelayakan yaitu "Layak"

Hasil nilai dari seluruh tahapan validasi oleh ahli materi, ahli media dan ahli pendidik selanjutnya akan digabungkan untuk memperoleh hasil rata-rata nilai media yang dikembangkan secara keseluruhan. Rata-rata nilai validasi materi dan rata-rata nilai validasi media dijumlahkan dan dirata-ratakan sehingga memperolah rata-rata nilai secara keseluruhan yaitu 3,49 dengan kategori "Sangat Baik" dan kriteria kelayakan yaitu "Layak" sehingga produk yang dikembangkan ini layak untuk digunakan sebagai media pembelajaran dalam kegiatan pembelajaran shalat untuk anak usia 5-6 tahun.

Anak usia dini merupakan individu yang memiliki berbagai potensi yang harus dikembangkan dan memiliki karakteristik khas yang tidak sama dengan orang dewasa (Sukma dkk, 2020). Menurut Ria dkk (2013) setiap anak perlu sekali mendapatkan stimulasi yang cukup dalam setiap aspek perkembangannya. Hal ini tidak terkecuali untuk aspek perkembangan agama anak terutama dalam hal beribadah. Sesuai dengan karakteristiknya, anak usia dini merupakan individu yang aktif, antusias, selalu memiliki rasa ingin tahu terhadap apa yang mereka lihat, mereka rasakan, serta mereka dengar. Dengan kata lain anak usia dini memerlukan adanya diberi stimulasi ataupun rangsangan untuk menunjang segala aspek yang dimiliki oleh anak.

Berkembang pesatnya teknologi pada masa sekarang ini dapat menjadi tantangan dalam mendidik anak usia dini. Seperti yang kita tahu bahwa di masa saat ini kita tidak bisa lepas dari yang namanya teknologi terutama gadged. Benda ini sudah menjadi benda yang tidak bisa lepas dari genggaman manusia saat ini. Bukan hanya dikalangan orang dewasa gadged juga sudah menjadi biasa ada di kalangan anak-anak. Maraknya penggunaan teknologi gadged dalam bentuk smarphone ini tidak bisa dipungkiri bahkan untuk anak-anak yang saat ini dikenal dengan generasi Alpha (Ria dkk, 2019). Penggunaan gadged saat ini sudah seperti kebutuhan utama bagi kita karena teknologi ini sendiri sudah sangat membantu kehidupan seharihari mulai dari komunikasi, belajar, bisnis, olahraga bahkan rekreasi. Saat ini, Sembilan dari sepuluh anak sudah menggunakan gadged bahkan sebelum anak bisa berjalan dan juga berbicara. Sering sekali kita menjumpai anak-anak yang memegang gadged saat orang tua mereka sedang melakukan kegiatan seperti berbelanja, berbincang, atau aktivitas lain dengan tujuan agar anak mereka tidak rewel. Kemudian apabila 
gadged diambil dari anak, maka anak akan mengamuk dan menangis. Meskipun teknologi ini sangat memudahkan kehidupan manusia, penggunaan gadged pada anak yang berlebihan dan tanpa aturan dapat menyebabkan masalah untuk anak yaitu anak menjadi kecanduan gadged.

Penggunaan teknologi ini membuat orang tua menjadi lupa bahwa ada banyak hal yang perlu diajarkan kepada anak mereka, salah satunya adalah mengenalkan tentang tatacara beribadah termasuk ibadah shalat. Menurut Ria dkk (2020) kesalahan pengasuhan orang tua akan membekas pada diri anak, termasuk juga penggunaan gadged yang berlebihan pada anak usia dini. Kebanyakan orang tua hanya berfikir bagaimana agar anak mereka tidak rewel dengan memberikan anak mereka gadged yang membuat anak mereka pun menjadi kecanduan. Hal ini tentunya akan dapat menghampat aspek perkembangan anak, apalagi bila orang tua benar-benar tidak memperhatikan stimulasi dan ransangan untuk perkembangan anak mereka. Maka dari itu, orang tua memiliki peran penting dalam pendidikan anak usia dini sebagai lingkungan pertama anak yang pertama kali mengenalkan ataupun mengajarkan segala hal pada anak.

Dalam pendidikan anak usia dini bukan hanya orang tua saja yang berperan, tetapi guru sebagai tenaga pendidik disekolah juga sangat berperan. Dalam kegiatan belajar mengajar disekolah, guru berperan sebagai fasilitator bagi anak. Dalam mengajar, guru PAUD haruslah memiliki pengetahuan pedagogis yang baik, terampil dalam berkomunikasi, serta memiliki pemahaman yang baik tentang aspek perkembangan anak. Menurut Rahman (dalam Ria Novianti dan Febrialismanto, 2020) mengatakan bahwa kompetensi pedagogi merupakan kemampuan guru dalam perencanaan, pelaksaan, dan penilaian hasil belajar peserta didik. Untuk menjadi guru yang professional, seorang guru harus dapat menguasai dan juga meningkatkan kemampuannya pedagoginya. Bukan hanya perencanaan, pelaksanaan, dan juga penilaian dalam pembelajaran saja. Tetapi juga dalam hal membuat dan juga memanfaatkan media pembelajaran. Menurut Hamalik (dalam Tejo Nurseto, 2011) pemanfaatan media pembelajaran dapat meningkatkan minat baru, keinginan, motivasi serta rangsangan belajar dalam kegiatan belajar mengajar. Didalam proses pembelajaran untuk anak usia dini, guru tidak hanya sekedar menjelaskan materi semata, tetapi dalam hal ini harus melibatkan segala aspek yang dimiliki anak usia dini sesuai dengan karakteristiknya, maka dari itu pemanfaat media dalam kegiatan pembelajaran anak akan sangat bermanfaat sebagai penguat dalam pembelajaran anak usia dini.

Dalam penelitian ini, peneliti berusaha mengembangkan sebuah produk yang dapat digunakan sebagai media pembelajaran. Produk yang dikembangan dalam penelitian dan pengembangan ini adalah sebuah media pembelajaran yang digunakan untuk meningkatkan kemampuan ibadah shalat anak usia 5-6 tahun yaitu media puzzle shalat edukatif. Berdasarkan pengamatan awal yang telah peneliti lakukan dilapangan terlihat bahwa dalam pembelajaran shalat untuk anak usia dini dilakukan dengan metode berceramah tanpa memanfaatkan media pembelajaran yang sesuai. Akibatnya beberapa anak menjadi tidak fokus dalam pembelajaran shalat, dan saat melakukan peraktek shalat, beberapa anak masih bingung menentukan gerakan, seperti bingung saat anak harus melakukan gerakan rukuk, dan i'tidal. Roofiq dkk (2019) mengatakan jika metodenya kurang menarik maka akan terjadi penghambatan dalam proses penerimaan dan juga pemahaman pada anak. Oleh karena itu kita sangat memerlukan media pembelajaran agar anak lebih paham dan tidak mudah jenuh di dalam pembelajaran.

Menurut Siti Sahara dkk (2020) penggunaan media secara kreatif akan memungkinkan peserta didik untuk belajar lebih baik dan meningkatkan performa mereka sesuai dengan tujuan yang ingin dicapai. Media puzzle shalat edukatif yang dikembangkan disini adalah media pembelajaran shalat berupa puzzle yang nantinya dapat dimainkan oleh anak. Media ini dikembangkan sekreatif mungkin agar dapat menjadi menyenangkan sekaligus mengedukasi anak apabila digunakan. Pada media ini nantinya akan dilengkapi dengan sebelas buah lampu biru dan satu buah lampu merah serta dilengkapi juga dengan suara audio doa dari setiap gerakan shalat. Prinsip kerja dari media ini adalah anak harus menyusun gambar gerakan shalat sesuai dengan urutan gerakan yang benar, apabila anak memasang gambar pertama lampu biri pertama akan menyala bersamaan dengan suara audio doa dari gerakan shalat yang pertama, kemudian apabila selanjutnya anak memilih gerakan yang kedua, maka lampu biru kedua akan menyala bersamaan juga dengan suara audio doa dari gerakan kedua, begitu seterusnya hingga gerakan shalat yang terakhir. Namun apabila ditengah pemilihan gerakan anak salah memilih gerakan maka yang menyala adalah lampu yang berwarna merah dan suara audio doa pun tidak akan terputar. Pengembangan media puzzle shalat edukatif ini diharapkan dapat menjadi alternative media yang dapat digunakan dalam pembelajaran shalat anak, sehingga tujuan dari pembelajaran dapat tercapai secara maksimal.

Tabel

Tabel 1. Total Perolehan Hasil Validasi Ahli Materi

\begin{tabular}{ccccc}
\hline Validasi ahli & Jumlah Skor & Rata-rata Skor & Kategori & Kelayakan \\
\hline Ahli Materi I & 18 & 2,57 & Baik & Layak \\
\hline Ahli Materi II & 24 & 3,43 & Sangat Baik & Layak \\
\hline Kesimpulan & 42 & 3,00 & Baik & Layak \\
\hline
\end{tabular}


Tabel 2. Total Perolehan Hasil Validasi Ahli Media

\begin{tabular}{ccccc}
\hline Validasi ahli & $\begin{array}{c}\text { Jumlah } \\
\text { Skor }\end{array}$ & $\begin{array}{c}\text { Rata-rata } \\
\text { Skor }\end{array}$ & Kategori & Kelayakan \\
\hline Ahli media I & 23 & 2,56 & Baik & Layak \\
\hline Ahli media II & 32 & 3,56 & Sangat Baik & Layak \\
\hline Kesimpulan & 55 & 3,06 & Baik & Layak \\
\hline
\end{tabular}

Tabel 3. Total Perolehan Hasil Validasi Ahli Pendidik

\begin{tabular}{ccccc}
\hline Validasi ahli & $\begin{array}{c}\text { Jumlah } \\
\text { Skor }\end{array}$ & $\begin{array}{c}\text { Rata-rata } \\
\text { Skor }\end{array}$ & Kategori & Kelayakan \\
\hline Ahli Pendidik I & 50 & 3,13 & Baik & Layak \\
\hline Ahli Pendidik II & 64 & 4,00 & Sangat Baik & Layak \\
\hline Ahli Pendidik III & 55 & 3,44 & Sangat Baik & Layak \\
\hline Ahli Pendidik IV & 61 & 3,81 & Sangat Baik & Layak \\
\hline Ahli Pendidik V & 64 & 4,00 & Sangat Baik & Layak \\
\hline Kesimpulan & $\mathbf{2 9 4}$ & $\mathbf{3 , 6 8}$ & Sangat Baik & Layak \\
\hline
\end{tabular}

Tabel 4. Total Perolehan Hasil Validasi Keseluruhan dari Ahli Materi, Ahli Media, dan Ahli Pendidik

\begin{tabular}{ccccc}
\hline Validasi ahli & $\begin{array}{c}\text { Jumlah } \\
\text { Skor }\end{array}$ & $\begin{array}{c}\text { Rata-rata } \\
\text { Skor }\end{array}$ & Presentase & Kelayakan \\
\hline Ahli Materi & 42 & 3,00 & Baik & Layak \\
\hline Ahli media & 55 & 3,06 & Baik & Layak \\
\hline Ahli Pendidik & 294 & 3,68 & Sangat Baik & Layak \\
\hline Kesimpulan & $\mathbf{3 9 1}$ & $\mathbf{3 , 4 9}$ & Sangat Baik & Layak \\
\hline
\end{tabular}

Gambar

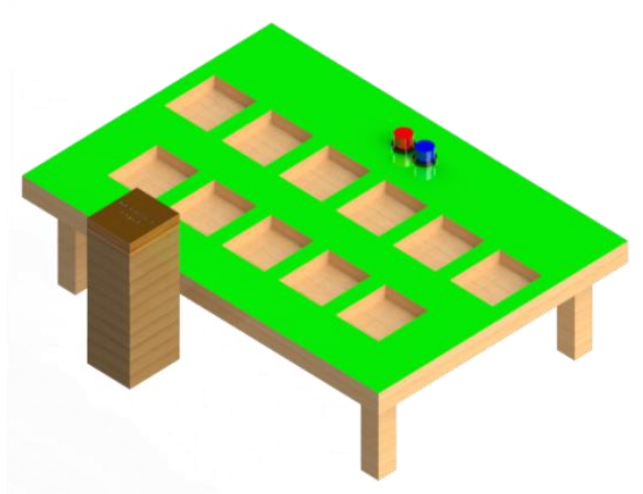

Gambar 1. Desian awal media menggunakan softwer

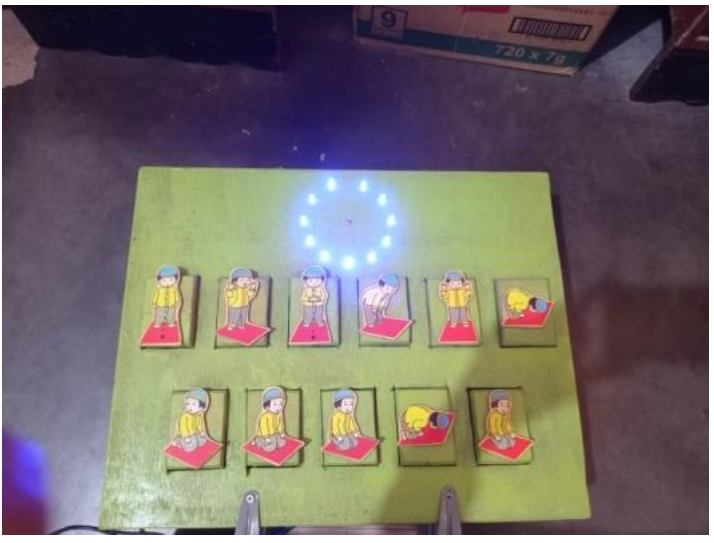

Gambar 2. Hasil akhir media

\section{SIMPULAN}

Bedasarkan hasil dari analisis dapat disimpulkan bahwa media puzzle shalat edukatif yang di kembangkan dalam penelitian ini dengan serangkaian langkah dan tahapan validasi ahi materi, ahli media, dan ahli pendidik dinyatakan "Layak" untuk meningkatkan kemampuan ibadah shalat anak usia 5-6 tahun. Hal tersebut dibuktikan dari hasil penilaian produk yang telah dilakukan oleh ahli materi yang menunjukkan bahwasanya media puzzle shalat edukatif ini dinyatakan "Layak" untuk aspek materi dengan rata-rata nilai yaitu 3,00, hasil peliaian yang dilakukan oleh ahli media juga menunjukkan bahwanya media puzzle shalat edukatif ini dinyatakan "Layak" dengan rata-rata nilai yaitu 3,06, kemudian hasil penilaian dari ahli pendidik juga menunjukkan bahwasanya media puzzel shalat edukatif ini dinyatakan "Layak" dengan rata-rata nilai yaitu 3,68. Sehingga perolehan rata-rata nilai dari produk yang dikembangkan secara keseluruhan adalah 3,49 dengan kategori "Sangat Baik" dan kriteria kelayakan "Layak" untuk meningkatkan kemampuan ibadah anak usia 5-6 tahun.

\section{UCAPAN TERIMA KASIH}

Dalam penulisan penelitian ini tentunya banyak ditemukannya hambatan serta rintangan yang penulis hadapi. Namun penulis dapat melalui semua nya berkat adanya bimbingan serta dukungan dari berbagai pihak baik secara forma maupun secara spiritual melaui doa. Untuk itu, pada kesempatan ini penulis ingin mengucapkan banyak terimakasih kepada: 1) Prof. Dr. Ir. H. Aras Mulyadi, M.Sc selaku Rektor Universitas Riau, 2) Prof. Dr. Mahdum, M.Pd selaku Dekan Fakultas Keguruan dan Ilmu Pendidikan Universitas Riau, 3) 
Ria Novianti, S.Psi, M.Pd selaku ketua jurusan IImu Pendidikan FKIP Universitas Riau yang telah membantu melancarkan penyusunan skripsi, 4) Enda Puspitasari, S.Pd, M.Pd selaku Koordinator Program Studi Pendidikan Guru Pendidikan Anak Usia Dini Fakultas Keguruan dan IImu Pendidikan Universitas Riau, 5) Drs. Zulkifli N, M.Pd selaku dosen pembimbing akademis, 6) Ria Novianti, S.Psi, M.Pd dan Febrialismanto, S.Pd, M.Pd selaku dosen pembimbing I dan dosen pembimbing II yang telah bersedia meluangkan waktu untuk memberikan bimbingan dan arahan selama penusunan skripsi, 7) Dr.Rita Kurnia, M.Ed dan Drs. Wilson, M.Si selaku validator ahli materi dan ahli media yang telah bersedia meluangkan waktu untuk mengisi angket penilaian produk dalam penelitian ini, 8) Seluruh jajaran Dosen dan Staf Program Studi Pendidikan Guru Pendidikan Anak Usia dini, 9) Kedua orang tua dan juga seluruh keluarga yang telah memberikan dukungan dan doa selama proses pembuatan skripsi, 10) Teman-teman semua, Joko Saprianto, Muhammad Asrofi Furqan, Mawarni, Yelin Nur Amalia, Vebry Chintya Simatupang, Silvi Mayasari, dan Yolanda Olivia yang telah membantu serta memberikan dukungan selama proses pembuatan skripsi, dan semua pihak yang tidak dapat disebutkan satu persatu yang telah membentu memberikan dukungan.

\section{DAFTAR PUSTAKA}

Guslinda \& Rita Kurnia. 2018. Media Pembelajaran Anak Usia Dini. Surabaya. CV. Jakad Publishing

Hazira Qudsyi. 2010. Optimalisasi Pendidikan Anak Usia Dini Melalui Pembelajaran yang Berbasis Perkembangan Otak. Jurnal Buletin Psikologi, 18(2), 91

Kamtini \& Mesra Khairani. 2018. Pengaruh Metode Eksperimen terhadap Kemampuan Sains Anak Usia 5-6 Tahun Di TK Salsa Percut Sei Tuan T.A 2014/2015. Jurnal Usia Dini, 4(2), 31

Muhammad Ihsan \& Uswatun Hasanah. 2018. Pendidikan Anak Usia Dini Menurut Konsep Islam. Jakarta. Amzah.

Muhammad Roofiq, Esron Rikardo Nainggolan, Hasta Herlan Asymar. 2019. Aplikasi Pembelajaran Sholat pada Anak Usia Dini Berbasis Android. Jurnal Ilmu Komputer, 8(2), 10

Ria Novianti, Enda Puspitasari, Daviq Chairilsyah. 2013. Pemetaan Kemampuan Guru Paud dalam Melaksanakan Asesmen Perkembangan Anak Usia Dini di Kota Pekanbaru. Jurnal SOROT, 8(1), 95

Ria Novianti \& Febrialismanto. The Analysis of Early Childhood Teachers' Pedagogical Content Knowledge. Jurnal of Educational Sciences. 4(2), 405

Ria Novianti, Febrialismanto, Enda Puspitasari \& Hukmi. Meningkatkan Kemampuan Orang Tua dalam Mendidik Anak di Era Digital di Kecamatan Koto Gasip Kabupaten Siak Provinsi Riau. Riau Jurnal of Empowerment, 3(3)183-190.

Ria Novianti, Hukmi, Ilga Maria. Generasi Alpha Tumbuh dengan Gadged dalam Genggaman. 8(2), 66

[10] Siti Sahara, Vitri Angraini Hardi, Moh. Fauziddin. 2020. Upaya Meningkatkan Hafalan Bacaan dan Gerakan Shalat dengan Media Audio Visual (Video) pada Anak Usia Dini di Desa Gerbang Sari Kecamatan Tapung Hilir Kabupaten Kampar. Journal on Teacher Education. 2(1), 139

Sugiyono. 2010. Metodologi Penelitian: Pendekatan Kuantitatif, Kualitatif, dan R\&D. Bandung. Alfabeta.

Sukma Cania, Ria Novianti, Daviq Chairilsyah. (2020). Pengaruh Media Glowing City terhadap Kemampuan Mengenal Bentuk Geometri pada Anak Usia Dini. Aulad: Journal on Early Childhood, 3(1), 53-60. https://doi.org/10.31004/aulad.v3i1.54

Suyadi \& Maulidya Ulfah. 2015. Konsep Dasar Paud. Bandung. PT Remaja Rosdakarya Offset.

Tejo Nurseto. 2011. Membuat Media Pembelajaran Yang Menarari. Jurnal Ekonomi \& Pendidikan, 8(1), 22 